\section{What's New in Federal Energy Management}

\author{
Program \\ Overview
}

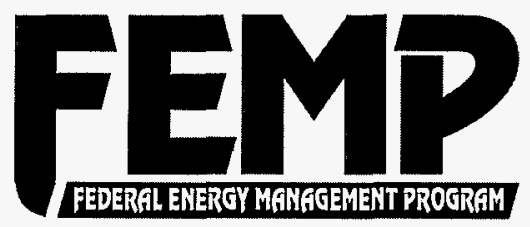

\title{
MASTER
}

\section{DISTRIBUTION OF THIS DOCUMENT IS UNLIMITED}

\section{Federal Energy Saver Showcases}

\section{Federal buildings feature advanced technologies and practices for energy efficiency, water conservation, and renewable energy.}

To promote widespread Federal energy efficiency, agencies are "showcasing" their best energy efficiency, water conserving, and solar and other renewable energy technologies.

To highlight these successful energyefficient projects, Executive Order 12902 directs agencies to designate at least one newly constructed or existing building as a showcase facility. At existing facilities, agencies must also try to incorporate cogeneration and indoor air quality improvements. Agencies are directed to develop and implement effective plans to make these showcase projects happen.

Project successes will show the strength of partnering with other agencies, energy services companies, utilities, and national laboratories, and of using the U.S. Department of Energy Federal Energy Management Program (FEMP) as a resource. The goal is Federal facilities operating at peak efficiency.

A Federal Energy Saver Showcase plaque is prominently displayed at
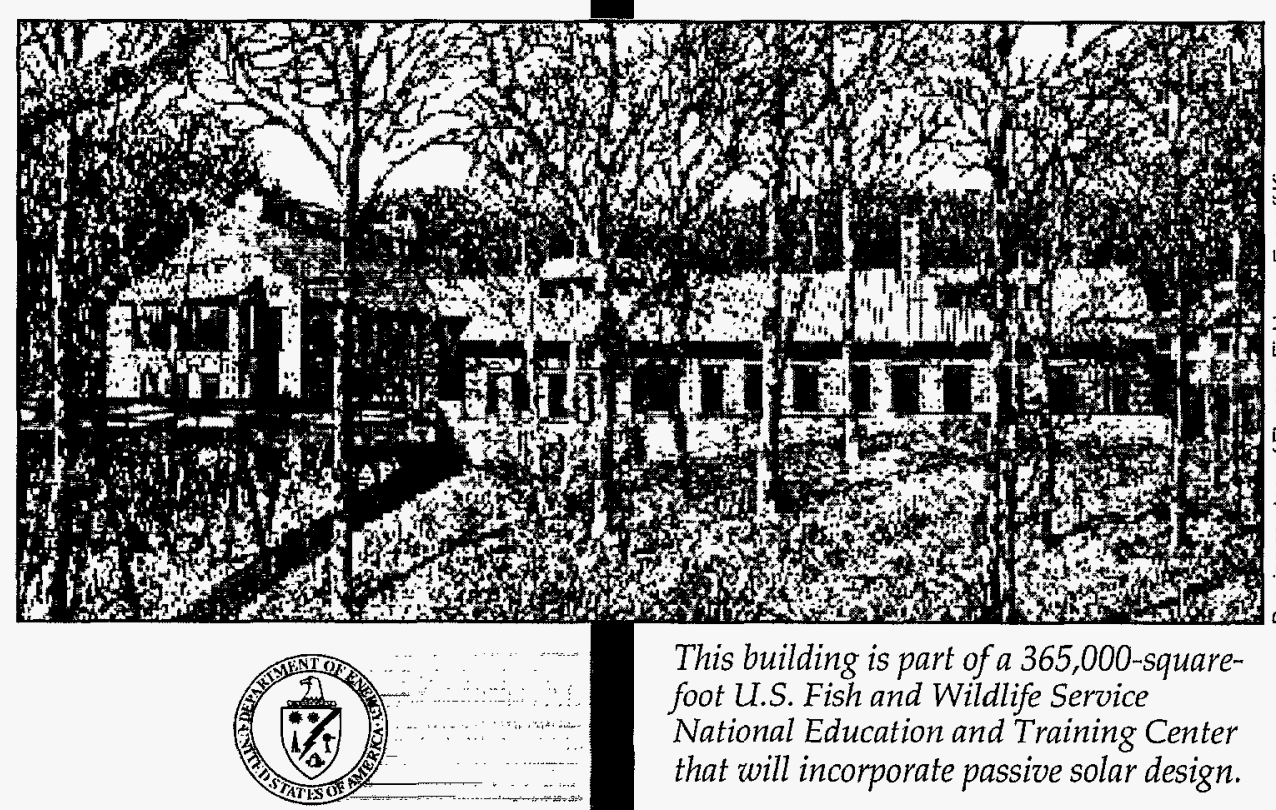

This building is part of a 365,000 -squarefoot U.S. Fish and Wildlife Service National Education and Training Center that will incorporate passive solar design. each showcase site, notifying visitors they are entering a government building that successfully conserves energy and water and saves taxpayer dollars.

\section{What are the benefits?}

The benefits of showcasing facilities are considerable:

- Awareness of energy-efficient and renewable energy technologies applicable to all Federal facilities is increased

- Technology transfer is facilitated through partnerships between agencies, utilities, manufacturers, and others

- Better projects are implemented through direct design assistance to selected showcase facilities

- Agency facilities are recognized for their efforts.

\section{How is a site selected for a showcase demonstration?}

Executive Order 12902 provides the following guidelines for designating buildings as showcase facilities:

- Buildings receive a high number of non-Federal visitors.

- Features of a project are replicable.

- Visitors can learn from site displays.

- Candidate buildings have historical significance.

FEMP suggests that the sites have an energy champion, use innovative financing methods, and be able to measure actual savings.

An agency can designate its headquarters (or a more unusual site) as a showcase facility. A few agencies have selected showcase projects at sites in different regions across the country. 


\section{How is a showcase facility created?}

Agencies can use the following steps

to create showcase facilities:

- Determine whether assistance is needed to develop a required general plan for implementating showcase demonstrations

- Identify showcases for designation (required by the Executive Order)

- Use or obtain a high-quality energy audit

- Seek design assistance and develop partnerships

- Submit designation form or letter and project description material to FEMP.

\section{What kinds of technologies are featured?}

As of March 1995, 47 projects in 17 agencies have been identified as showcase projects. Nearly $90 \%$ of the projects involve high-efficiency lighting, and $70 \%$ will include the installation of more efficient heating, ventilating, and cooling systems.

Lighting projects include highenergy-saving lighting retrofits, which incorporate occupancy sensors and daylighting strategies. Chiller projects involve replacing existing electric chillers with high-efficiency ones that do not use chlorofluorocarbons.

Solar energy and other renewables are being considered for about half the showcase facilities. The renewable technology most favored is solar water heating, which is planned for use in more than one-third of the identified projects. Other technologies include:

- Energy management control systems

- Cogeneration

- Building envelope

- Landscape improvements.

\section{How can agencies fund} showcase facility projects?

FEMP offers several methods to fund showcase facility projects:

- Energy Savings Performance Contracting-FEMP provides direct project assistance, broad policy guidance, and training materials.

- Utility incentives-FEMP works directly with other Federal agencies and utilities to ensure that individual facilities take maximum advantage of the utility-sponsored financial and technical assistance programs.

- Agency appropriations and operations and maintenance-Agencies can use existing appropriations for investments in energy efficiency. Showcasing facilities do not necessarily cost more; funds are just invested more wisely.

\section{How does FEMP help agencies?}

FEMP provides the following services to help agencies create showcase facilities:

- Design Assistance-The design assistance program provides agencies with direct project implementation support and serves as the central focus for expanding the use of renewable energy in Federal facilities.

- SAVEnergy Action Plans-Facility managers are provided with specific action plans for installing measures that are monitored through a projecttracking system. The program helps agencies identify the best, most costeffective energy, water, and renewable energy projects.

- Increased Technology AwarenessSupport is provided to all Federal agencies to facilitate information transfer on energy and water resource management within the Federal and private sectors.

- Development of Promotional Materials-Federal agencies receive support through publications and electronic media, which help facility managers make the best decisions on energy-saving opportunities.

- Interagency Coordination-FEMP is the lead office for coordinating the implementation of the Executive Order. It facilitates partnerships between agencies and the private sector to assist in leveraging funding and other services.

\section{What are some current showcase projects?}

The U.S. Fish and Wildlife Service is designating a new training center in the mountains of West Virginia as one of its showcase projects. Campus facililties feature passive solar design, energy-efficient building systems, materials with high recycled content, materials and finishes with low environmental impact, and configuration of storm water management systems as demonstration wetlands.

Water-efficient technologies are being demonstrated at a typical Federal office building in the Denver Federal Center. The demonstration represents a partnership among Federal agencies, a water utility, and four manufacturers. Low-water-use plumbing fixtures and a landscape irrigation control system have been installed and evaluated. A report is being developed to illustrate the significant water and energy savings achieved through water conservation.

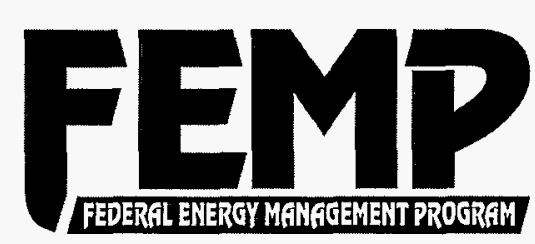

\section{For More Information}

FEMP Help Desk:

(800) DOE-EREC (363-3732)

Internet: $\mathrm{http}: / / \mathrm{www}$.eren.doe.gov/femp

Karen Thomas

(202) 651-7536

National Renewable Energy Laboratory

Anne Sprunt Crawley

Technical Assistance Team Leader

(202) 586-1505

Fax: (202) 586-3000

Mark Ginsberg, Director

Federal Energy Management

Program, FE-90

U.S. Department of Energy

1000 Independence Ave., SW

Washington, DC 20585

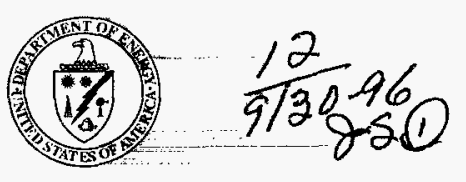

Produced for the U.S. Department of Energy (DOE) by the National Renewable Energy Laboratory, a DOE national laboratory

A revision of DOE/GO-10095-172 DOE/GO10096-295

DE96013070

August 1996 


\section{DISCLAMMER}

Portions of this document may be illegible in electronic image products. Images are produced from the best available original document. 


\section{DISCLAIMER}

This report was prepared as an account of work sponsored by an agency of the United States Government. Neither the United States Government nor any agency thereof, nor any of their employees, makes any warranty, express or implied, or assumes any legal liability or responsibility for the accuracy, completeness, or usefulness of any information, apparatus, product, or process disclosed, or represents that its use would not infringe privately owned rights. Reference herein to any specific commercial product, process, or service by trade name, trademark, manufacturer, or otherwise does not necessarily constitute or imply its endorsement, recommendation, or favoring by the United States Government or any agency thereof. The views and opinions of authors expressed herein do not necessarily state or reflect those of the United States Government or any agency thereof. 